\title{
Effects of Corporate Disclosure on Share Price Movement: An Empirical Study on Listed Companies in Dhaka Stock Exchange
}

\author{
AHM Yeaseen Chowdhury ${ }^{*}$, M Shahin Sarwar², and Md. Kaysher Hamid ${ }^{3}$ \\ ${ }^{1}$ Associate Professor, Faculty of Business Studies, Bangladesh University of Professionals, Dhaka, Bangladesh \\ ${ }^{2}$ Assistant Professor, Faculty of Business Studies, Bangladesh University of Professionals, Dhaka, Bangladesh \\ ${ }^{3}$ Lecturer, Faculty of Business Studies, Bangladesh University of Professionals, Dhaka, Bangladesh \\ Email: yeaseenchy@bup.edu.bd ${ }^{1}$, mshahinsarwar@gmail. $\mathrm{com}^{2}$, mkhamid21@gmail. com ${ }^{3}$
}

\begin{abstract}
The purpose of this study is to investigate the effects of corporate disclosure on share price movement of listed companies in Dhaka Stock Exchange (DSE) of Bangladesh. For this, 41 companies listed with DSE under different industries i.e. bank; cement and engineering; food, fuel and power; insurance; pharmaceuticals and chemicals; and textile, were studied for the period of 2016 and 2017. After calculating the immediate ten days average stock price of before and after dividend declaration day, this study has used paired samples t- test to find out the statistical mean difference of stock price for individual company and analysis of variance (ANOVA) test to find out the statistical significance of stock price movement across industry. After the analysis, this study has found no statistical valid effects of corporate disclosure on price movement for the selected listed companies in DSE. But, across the industry, this study has found statistically significant difference of price change between before and after corporate disclosure.
\end{abstract}

Keywords: Corporate disclosure, dividend announcement, DSE, price movement.

\section{Introduction}

Corporate disclosure is a very important corporate event through which corporations communicate with their investors. Investors take their investment decisions based on different corporate disclosures. Dividend declaration is one of the most vital corporate disclosures. It gives a signal about the earnings of the dividend declared firms. Hence, it has an impact on market price of share. But, globally, there are mixed evidences about the relationship between corporate disclosure and share price movement in the stock market.

This research work provides an academic literature on corporate disclosure, more specifically dividend declaration and its' impact on share price in stock market of Bangladesh. Like any other country, stock market is an important ingredient of the financial system in Bangladesh. In view of the rapidly increasing role of the stock market, volatility in stock prices can have significant implications on the performance of the financial sector as well as the entire economy. As there is a mixed evidence of the impact of dividend declaration on stock price movement in global market, this study would attempt to find out this impact in Bangladesh context.

\section{$2 \quad$ Literature Review}

In a company, one of the major responsibilities of the board of directors is to ensure that shareholders and other stakeholders are provided with high-quality disclosures on the financial and operating results of the concerned entity. The quality of financial disclosure depends significantly on the strength of the financial reporting standards (FRS) on the basis of which the financial information is prepared and reported. In most circumstances, the financial reporting standards required for corporate reporting are contained in the generally accepted accounting principles recognized in the country where the entity is operating. In line with that there are also established rules relating to the disclosure of dividend for a company.

The goal of any corporate entity is to maximize the value of shareholders' investment in the firm. Managers pursue this goal through their investment and financing decisions. Apart from the investment 
and financing decisions, managers need to decide on regular basis whether to pay out the earning to shareholders, reducing the agency problem [1]. However, the question remains whether paying out of earnings would essentially create value for the shareholders or not. A dividend payment provides cash flow to the shareholders but reduces firm's recourses for investment, thus, this is a dilemma in finance literature. A great deal of theoretical and empirical research on dividend effects has been done over the last several decades.

Theoretically, cash dividend means giving reward to the shareholders that is something they already own in the company; hence this will be offset by the decline in stock value [2]. In an ideal world, therefore, dividend payments would have no impact on the shareholders' value [3]. In the real world, however, a change in the dividend policy is often followed by change in the market value of stocks. The economic argument for investors' preference to dividend income was offered by Graham [4]. Subsequently, Walter [5] and Gordon [6,7] forwarded the dividend relevancy idea, which has been formalized into a theory, postulating that current stock price would reflect the present value of all expected dividend payments in the future.

Kumar [8] conducted a research in India from 2012 to 2014 on stock market reaction to dividend announcement and found that increase in dividend push the stock price up and decrease in dividend push the stock price down. Another similar research conducted by Dasilas and Leventis [9] in Greek stock market on stock market reaction from 2000 to 2004 on dividend announcement found significant market reaction in dividend change announcement. Khanal and Mishra [10] conducted a research on stock price reaction because of dividend announcement for the period of 2006 to 2012 and found on average stock price react positively to dividend announcement. However, the number of literatures on this area in perspective of Bangladesh is very limited. Therefore, this research aims to study this issue in context of Bangladesh.

\section{$3 \quad$ Objective of the Study}

The objective of this study is to find out the impact of dividend disclosure on stock price movement in DSE.

\section{Statement of the Problem}

Dividend policy is very crucial for any firm. Usually, the firms distribute a portion of earnings to the shareholders as dividends and retain the remainder for further investment or as a reserve basing on their dividend policy. It is well evidenced that the movement of stock price is heavily influenced by the different corporate disclosure like Dividend Declaration, Financial Statement (annually, half-yearly, quarterly) Publication etc. In the listing rules and regulation of Bangladesh Securities and Exchange Commission (BSEC), there are rules regarding the disclosure of different corporate information on timely basis for the betterment of general shareholder and prohibiting insider trading.

Few researches found statistical valid relationship between dividend disclosure and stock price movement, but few researches didn't find statistical valid relationship; which makes this relationship controversial. Again, there are enormous researches available on developed stock market on this issue, but the evidences are limited in Bangladesh stock market. Hence, this study believes, there is an opportunity to work on this issue in stock market of Bangladesh. Because of these reasons, this study sets the aim to study the effect of dividend disclosure on stock price movement of selected listed companies in Dhaka Stock Exchange (DSE).

\section{Methodology}

\subsection{Data Source}

This research has primarily been conducted basing on secondary data. Data on dividend, share price, and other related aspects have been collected from the official website of Dhaka Stock Exchange (DSE). 


\subsection{Sample Descriptions}

The population for this research is the listed companies of DSE having a consistent track record of dividend declaration, annual report publication, and providing price sensitive information as corporate disclosure. The number of total listed companies is 347. This study didn't consider mutual funds, Z Category securities, N Category securities, and the securities for which firms didn't declared dividends during sample year of 2016 to 2017. Finally, 41 companies met sample criteria and these were found convenient for this study. However, representation from all industry is available in the sample.

\subsection{Method of Analysis}

This study, at first, calculated the immediate ten days average stock price of before and after dividend declaration day for the sample firms. Then, paired samples t- test is used to compare the mean of each sample firms to find out the statistical mean difference of stock price between before and after dividend declaration. After that, Analysis of Variance (ANOVA) test has been carried out in order to find out the statistical significance of stock price movement across industry because of dividend declaration.

\subsection{Hypotheses}

In order to find out the relationship between divided disclosure and share price movement, the following hypothesis would be tested.

$\mathrm{H}_{\mathrm{O}}$ : Stock price movement is indifferent to the firms' dividend declaration.

$\mathrm{H}_{\mathrm{A}}$ : Stock price movement is influenced by the firms' dividend declaration.

\section{$6 \quad$ Analysis and Findings}

\subsection{Share Price Changes of Before and After Dividend Declaration Date}

This study used simple average of stock prices for both ten days before and after dividend declaration date of all selected stocks to make comparison. Dividend declaration date is considered as zero date. Then, percentage change of these two average prices is calculated to find out the difference. Table 1 shows the result for all selected stocks.

Table 1. Before dividend declaration price and after dividend declaration price

\begin{tabular}{clcccc}
\hline SL No & Name of the Firms & Dividend Date & $\mathrm{P}_{1}$ & $\mathrm{P}_{2}$ & \% Changes \\
\hline 1 & AB Bank Limited & $30-04-17$ & 21.42 & 19.71 & $7.98 \%$ \\
2 & ACI Limited & $27-06-16$ & 442.18 & 460.53 & $-4.15 \%$ \\
3 & ACI Formulations Ltd & $28-04-16$ & 182.67 & 156.04 & $14.58 \%$ \\
4 & Aftab Automobiles & $30-10-16$ & 49.31 & 49.23 & $0.16 \%$ \\
5 & Ambee Pharma & $23-11-16$ & 438.61 & 376.08 & $14.26 \%$ \\
6 & Apex Foods Limited & $30-10-16$ & 151.98 & 141.98 & $6.58 \%$ \\
7 & Apex Spinning \& Knitting Mills Ltd & $30-10-16$ & 121.24 & 128 & $-5.58 \%$ \\
8 & Bank Asia Limited & $17-04-17$ & 17.76 & 16.52 & $6.98 \%$ \\
9 & Bata Shoe Company (Bangladesh) Ltd & $27-04-17$ & $1,125.86$ & $1,130.56$ & $-0.42 \%$ \\
10 & Beximco Synthetics & $09-10-16$ & 6.23 & 6.07 & $2.57 \%$ \\
11 & Beximco Pharma & $09-10-16$ & 81.76 & 77.33 & $5.42 \%$ \\
12 & BRAC Bank & $21-03-17$ & 73.38 & 87.02 & $-18.59 \%$ \\
13 & British American Tobacco Bangladesh & $28-02-17$ & $2,500.85$ & $2,495.61$ & $0.21 \%$ \\
14 & Delta Spinners Ltd. & $01-11-16$ & 8.58 & 8.47 & $1.28 \%$ \\
15 & Dhaka Electric Supply Company Ltd. & $23-10-16$ & 53.19 & 52.11 & $2.03 \%$ \\
16 & Eastern Insurance Company Limited & $30-04-17$ & 29.03 & 29.21 & $-0.62 \%$ \\
17 & Eastern Lubricants Blenders Limited & $13-11-16$ & $1,259.52$ & 907.57 & $27.94 \%$ \\
\hline
\end{tabular}




\begin{tabular}{clcccc}
\hline SL No & Name of the Firms & Dividend Date & $\mathrm{P}_{1}$ & $\mathrm{P}_{2}$ & \% Changes \\
\hline 18 & Fareast Islami Life Insurance Com. & $20-08-17$ & 72.7 & 76.54 & $-5.28 \%$ \\
19 & Heidelberg Cement Bangladesh Limited. & $01-03-17$ & 556.16 & 533.69 & $4.04 \%$ \\
20 & Islami Bank Bangladesh Limited. & $02-04-17$ & 43.15 & 33.53 & $22.29 \%$ \\
21 & Jamuna Bank Ltd. & $27-04-17$ & 18.49 & 18.91 & $-2.27 \%$ \\
22 & Meghna Cement Mills Limited & $06-11-16$ & 101.51 & 96.5 & $4.94 \%$ \\
23 & Mercantile Bank & $26-02-17$ & 17.56 & 19.16 & $-9.11 \%$ \\
24 & National Bank Limited & $02-05-17$ & 13.81 & 13.87 & $-0.43 \%$ \\
25 & National Life Insurance Company Limited & $19-07-17$ & 177.35 & 180.86 & $-1.98 \%$ \\
26 & One Bank Limited & $02-04-17$ & 23.22 & 23.56 & $-1.46 \%$ \\
27 & Premier Bank & $27-04-17$ & 12.32 & 12.31 & $0.08 \%$ \\
28 & Prime Bank & $30-03-17$ & 19.78 & 20.3 & $-2.63 \%$ \\
29 & Prime Textile Spinning Mills. & $31-10-16$ & 22.88 & 21.54 & $5.86 \%$ \\
30 & Pubali Bank & $13-03-17$ & 25.49 & 24.8 & $2.71 \%$ \\
31 & Reckitt Benckiser & $02-05-17$ & $1,506.85$ & $1,522.64$ & $-1.05 \%$ \\
32 & Renata Ltd & $17-05-16$ & $1,246.73$ & $1,150.75$ & $7.70 \%$ \\
33 & S. Alam Cold Rolled Steel & $02-10-16$ & 26.74 & 26.23 & $1.91 \%$ \\
34 & Saiham textile mills ltd. & $30-10-16$ & 14.01 & 13.84 & $1.21 \%$ \\
35 & Social Islami Bank Ltd & $22-02-17$ & 20.91 & 22.15 & $-5.93 \%$ \\
36 & Southeast Bank & $09-04-17$ & 21.56 & 20.52 & $4.82 \%$ \\
37 & Square Pharma & $17-10-16$ & 269.39 & 267.34 & $0.76 \%$ \\
38 & Square Textiles Ltd. & $02-08-16$ & 70.14 & 71.79 & $-2.35 \%$ \\
39 & Standard Bank & $23-03-17$ & 14.19 & 13.13 & $7.47 \%$ \\
40 & Trust Bank & $15-03-17$ & 25.55 & 28.37 & $-11.04 \%$ \\
41 & Uttara Bank & $13-04-17$ & 25.94 & 24.88 & $4.09 \%$ \\
\hline
\end{tabular}

*Note: $\mathrm{P}_{1}$ represents average price of 10 days before dividend declaration and $\mathrm{P}_{2}$ represents average price of 10 days after dividend declaration.

In the sample data it has been observed that Eastern Lubricants Blenders Limited has the highest price increase i.e. $27.94 \%$ after dividend declaration followed by Islami Bank Bangladesh Limited of $22.29 \%$ price increase. On the other hand, BRAC has the highest price decrease of $18.59 \%$ followed by Trust Bank Ltd of $11.04 \%$ after dividend declaration. And, for other sample firms, price changes are statistically insignificant. This evidence is consistent with many developed capital markets where relationship was found to be mixed.

In the table, it is also found that 16 companies' share prices increased, and 25 companies' share prices fell following dividend declaration out of 41 sample companies i.e. as far as the direction of relationship is concerned dividend declaration has mixed relationship but cumulatively these differences are statistically not significant. But this is beyond the scope of this paper to really attribute the percentage change in share price after dividend declaration for all companies with dividend declaration alone. It simply suggests that there may be many other factors besides dividend declaration for such positive or negative share price changes.

\subsection{Analysis of The Impact of Dividend Declaration on Share Price Change for Individual Company}

The paired samples t- test is chosen to study the statistical mean difference of stock price before and after the dividend disclosure. This study found that at $5 \%$ or even $10 \%$ significance level, the null hypothesis can't be rejected. That means, there is no difference between before dividend declaration price and after dividend declaration price for individual companies.

The reason for this might be that investors receive information on dividend declaration much before it is officially declared. So, as much price adjustments take place much before the immediate past and post period of dividend declaration. Therefore, when dividend is declared in the annual general meeting, it becomes no new information to the investors as investor or market has already discounted that piece of information much before. 
Table 2. Result of paired samples t- test

\begin{tabular}{llcccc}
\hline \multicolumn{2}{l}{ Paired Samples Statistics } & Mean & N & Std. Deviation & Std. Error Mean \\
\hline \multirow{2}{*}{ Pair 1} & Ten Days before Average Price & 266.0976 & 41 & 523.21800 & 81.71292 \\
\cline { 2 - 6 } & Ten Days after Average Price & 253.1524 & 41 & 504.89431 & 78.85124 \\
\hline
\end{tabular}

\begin{tabular}{lllll}
\hline \multicolumn{2}{l}{ Paired Samples Correlations } & & & \\
\hline \multicolumn{2}{l}{ Ten Days before Average Price \& Ten Days after Average Price } & 41 & Correlation & Sig. \\
\hline Pair 1 & T & .994 & .000 \\
\hline
\end{tabular}

\begin{tabular}{|c|c|c|c|c|c|c|c|c|c|}
\hline \multicolumn{10}{|c|}{ Paired Samples Test } \\
\hline & & \multicolumn{5}{|c|}{ Paired Differences } & \multirow{3}{*}{$\mathrm{t}$} & \multirow{3}{*}{ df } & \multirow{3}{*}{$\begin{array}{l}\text { Sig. }(2- \\
\text { tailed) }\end{array}$} \\
\hline & & \multirow[t]{2}{*}{ Mean } & \multirow{2}{*}{$\begin{array}{c}\text { Std. } \\
\text { Deviation }\end{array}$} & \multirow{2}{*}{$\begin{array}{l}\text { Std. } \\
\text { Error } \\
\text { Mean }\end{array}$} & \multicolumn{2}{|c|}{$\begin{array}{c}95 \% \text { Confidence Interval } \\
\text { of the Difference }\end{array}$} & & & \\
\hline & & & & & Lower & Upper & & & \\
\hline Pair 1 & $\begin{array}{l}\text { Ten Days before Average } \\
\text { Price - Ten Days after } \\
\text { Average Price }\end{array}$ & 12.94512 & 57.55372 & 8.98838 & -5.22107 & 31.11132 & 1.440 & 40 & .158 \\
\hline
\end{tabular}

\subsection{Analysis of The Impact of Dividend Declaration on Share Price Change Across The Industry}

This study categorized 41 sample firms under six industries to see the price changes before and after dividend declaration across the industries. These industries are Bank; Cement and Engineering; Food, fuel and Power; Insurance; Pharmaceuticals \& Chemicals; and Textile.

Table 3. Result of ANOVA test

\begin{tabular}{lccccc}
\hline ANOVA Test & & & & & \\
\hline Price Difference & Sum of Squares & df & Mean Square & F & Sig. \\
\hline & 30177.106 & 5 & 6035.421 & 2.064 & .093 \\
\hline Between Groups & 102320.104 & 35 & 2923.432 & & \\
\hline Within Groups & 132497.210 & 40 & & & \\
\hline Total & & & & & \\
\hline
\end{tabular}

\begin{tabular}{|c|c|c|c|c|c|c|}
\hline \multicolumn{7}{|c|}{ Multiple Comparisons } \\
\hline \multicolumn{7}{|c|}{ Dependent Variable: Price Difference (LSD) } \\
\hline \multirow[b]{2}{*}{ (I) Industry } & \multirow[b]{2}{*}{$(\mathrm{J})$ Industry } & \multirow[b]{2}{*}{$\begin{array}{c}\text { Mean Difference } \\
(\mathrm{I}-\mathrm{J})\end{array}$} & \multirow[b]{2}{*}{ Std. Error } & \multirow[b]{2}{*}{ Sig. } & \multicolumn{2}{|c|}{$95 \%$ Confidence Interval } \\
\hline & & & & & $\begin{array}{l}\text { Lower } \\
\text { Bound }\end{array}$ & $\begin{array}{l}\text { Upper } \\
\text { Bound }\end{array}$ \\
\hline \multirow{5}{*}{ Bank } & Cement and Engineering & -7.28062 & 30.22536 & .811 & -68.6414 & 54.0801 \\
\hline & Food, Fuel \& Power & $-92.33062^{*}$ & 30.22536 & .004 & -153.6914 & -30.9699 \\
\hline & Insurance & 2.24688 & 34.01752 & .948 & -66.8124 & 71.3061 \\
\hline & Pharmaceuticals \& Chemicals & -19.36062 & 23.41246 & .414 & -66.8905 & 28.1692 \\
\hline & Textile & .84188 & 25.88345 & .974 & -51.7043 & 53.3881 \\
\hline \multirow{4}{*}{$\begin{array}{l}\text { Cement and } \\
\text { Engineering }\end{array}$} & Food, Fuel \& Power & $-85.05000^{*}$ & 38.23239 & .033 & -162.6659 & -7.4341 \\
\hline & Insurance & 9.52750 & 41.29570 & .819 & -74.3072 & 93.3622 \\
\hline & Pharmaceuticals \& Chemicals & -12.08000 & 33.11022 & .717 & -79.2973 & 55.1373 \\
\hline & Textile & 8.12250 & 34.90124 & .817 & -62.7308 & 78.9758 \\
\hline \multirow{2}{*}{$\begin{array}{l}\text { Food, Fuel \& } \\
\text { Power }\end{array}$} & Insurance & $94.57750^{*}$ & 41.29570 & .028 & 10.7428 & 178.4122 \\
\hline & Pharmaceuticals \& Chemicals & $72.97000^{*}$ & 33.11022 & .034 & 5.7527 & 140.1873 \\
\hline
\end{tabular}




\begin{tabular}{|c|c|c|c|c|c|c|}
\hline \multicolumn{7}{|c|}{ Multiple Comparisons } \\
\hline \multicolumn{7}{|c|}{ Dependent Variable: Price Difference (LSD) } \\
\hline \multirow{4}{*}{ (I) Industry } & \multirow{3}{*}{$(\mathrm{J})$ Industry } & \multirow{3}{*}{$\begin{array}{c}\text { Mean Difference } \\
(\mathrm{I}-\mathrm{J})\end{array}$} & \multirow{3}{*}{ Std. Error } & \multirow{3}{*}{ Sig. } & \multicolumn{2}{|c|}{$95 \%$ Confidence Interval } \\
\hline & & & & & Lower & Upper \\
\hline & & & & & Bound & Bound \\
\hline & Textile & $93.17250 *$ & 34.90124 & .011 & 22.3192 & 164.0258 \\
\hline \multirow{2}{*}{ Insurance } & Pharmaceuticals \& Chemicals & -21.60750 & 36.60473 & .559 & -95.9190 & 52.7040 \\
\hline & Textile & -1.40500 & 38.23239 & .971 & -79.0209 & 76.2109 \\
\hline $\begin{array}{l}\text { Pharmaceuticals } \\
\text { \& Chemicals }\end{array}$ & Textile & 20.20250 & 29.20047 & .494 & -39.0776 & 79.4826 \\
\hline
\end{tabular}

*. The mean difference is significant at the 0.05 level.

This study found that at $10 \%$ significance level, the null hypothesis can be rejected. That means at $10 \%$ significance level, there is significant difference across the industry between ten days before average stock price and ten days after average stock price.

But in the individual pair, only Food, Fuel and Power industry is significant with other industries even at 5\% significance level. Probable reason for this significance is wide range of this industry. It covers three types of industries i.e. Food, Fuel, and Power. But remaining industries are insignificant with each other. So, there is difference between before dividend declaration price and after dividend declaration price across the industries.

\subsection{Empirical Findings and Discussions}

This study investigates the stock price reaction to the announcement of dividends before 10 days of the announcement as well as stock price reaction to the announcement of dividends after 10 days of the announcement. From the above analysis, it can be said that, based on the result of paired samples ttest, for individual firm, there is no impact of dividend disclosure on share price movement. On the other hand, to find out sector base difference between before dividend declaration price and after dividend declaration price this study used ANOVA test. From the ANOVA test, this study found that there is no statistical evidence to accept the null hypothesis and concluded that there is significant difference between before dividend declaration price and after dividend declaration price.

\section{Conclusion}

The relationship between corporate disclosure and share price movement has been studied by many researchers in different scopes. Their researches have provided mixed evidences. Some have identified significant impact of corporate disclosure on share price movement and others have found insignificant impact. However, the number of literatures on this area in perspective of the stock market of Bangladesh is very limited. So, this study aimed to reveal the effect of corporate disclosure, more specifically dividend disclosure, on stock price movement in Dhaka Stock Exchange (DSE) of Bangladesh. After analyzing data of 41 companies from different industries for the period of 2016 and 2017, this study has found no significant impact of dividend declaration on share price movement for individual companies. However, in terms of industry, this study has observed that there is a price difference between before and after dividend declaration.

\section{References}

1. Jensen, M. C., \& Meckling, W. H. (1976). Theory of the firm: Managerial behavior, agency costs and ownership structure. Journal of Financial Economics, 3(4), 305-360.

2. Porterfield, J. T. (1965). Investment decisions and capital costs. Prentice-Hall.

3. Miller, M. H. \& Modigliani, F. (1961), Dividend Policy, Growth and The Valuation of Shares. The Journal of Business, 34, 411-433. 
4. Graham, B., Dodd, D. L. F., \&Tatham, C. (1951). Security Analysis. Principles and Technique. McGraw-Hill Book Company.

5. Walter, J. E. (1956). Dividend policies and common stock prices. The Journal of Finance, 11(1), 29-41.

6. Gordon, M. J. (1959). Dividends, earnings, and stock prices. The Review of Economics and Statistics, 41(2), 99105.

7. Gordon, M. J. (1962), The Savings, Investment and Valuation of the Corporation, Review of Economics and Statistics, 44(1), 37-51.

8. Kumar, S. (2017). New evidence on stock market reaction to dividend announcements in India. Research in International Business and Finance, 39, 327-337.

9. Dasilas, A., \& Leventis, S. (2011). Stock market reaction to dividend announcements: Evidence from the Greek stock market. International Review of Economics \& Finance, 20 (2), 302-311

10. Khanal, R. A., \& Mishra, K. A. (2017). Stock price reactions to stock dividend announcements: A case from a sluggish economic period. The North American Journal of Economics and Finance, 42, 338-345. 